\title{
Effect of deficit irrigation and in situ moisture conservation on soil moisture content and frequency of irrigation in kiwifruit cultivar Allison
}

\author{
Preet Pratima $^{1^{*}}$, N. Sharma ${ }^{1}$ and Rajesh Kaushal ${ }^{2}$ \\ ${ }^{1}$ Department of Fruit Science, Dr Y. S. Parmar University of Horticulture and Forestry, Nauni, Solan -173230 \\ (H.P.), INDIA \\ ${ }^{2}$ Department of Soil Science and Water Management, Dr Y. S. Parmar University of Horticulture and Forestry, \\ Nauni, Solan -173230 (H.P.), INDIA \\ *Corresponding author. E-mail: preetepitome@gmail.com
}

Received: January 13, 2016; Revised received: August 5, 2016; Accepted: November 12, 2016

\begin{abstract}
The effect of deficit irrigation and in situ moisture conservation in kiwifruit cv. Allison vines was studied during the years 2011 and 2012 in the Department of Fruit Science, Dr. Y. S. Parmar University of Horticulture and Forestry, Solan, HP, India. Soil moisture content and frequency of irrigation were investigated in kiwifruit in response to deficit irrigation and in situ moisture conservation techniques. Seven treatments viz., irrigation at 80 per cent Field Capacity $\left(T_{1}\right), 60$ per cent Field Capacity $\left(T_{2}\right)$ and 40 per cent Field Capacity $\left(T_{3}\right), 60$ per cent Field Capacity (FC) plus grass mulch $\left(T_{4}\right)$ or black polythene $\left(T_{5}\right)$ and 40 per cent FC plus grass mulch $\left(T_{6}\right)$ or black polythene $\left(T_{7}\right)$ were applied from March to October with three replications in Randomized Block Design (RBD). During the year 2011, the soil moisture content under kiwifruit vines was highest under the treatment $T_{1}(15.3,16.9)$, followed by $T_{5}$ $(15.2,16.8)$ and $T_{4}(14.9,16.6)$ at $30 \mathrm{~cm}$ and at $60 \mathrm{~cm}$ soil depth, respectively. Whereas, during the year 2012 , the soil moisture content under kiwifruit vines was highest under the treatment $T_{1}(14.9,16.4)$, followed by $T_{5}(15.0,16.3)$ and $\mathrm{T}_{4}(14.6,16.1)$ at $30 \mathrm{~cm}$ and at $60 \mathrm{~cm}$ soil depth, respectively. However,the least soil moisture content was, however, observed under $T_{3}(11.0,12.8)$ at $30 \mathrm{~cm}$ and $60 \mathrm{~cm}$ soil depth, respectively, during the year 2011 , similarly, during the year 2012, the least soil moisture content was also observed under $T_{3}(10.6,12.7)$ at $30 \mathrm{~cm}$ and $60 \mathrm{~cm}$ soil depth, respectively. The frequency of irrigation was highest under $T_{1}$ (16 irrigations) followed $T_{2}$ (10 irrigations) while the least was recorded under $T_{6}$ and $T_{7}$ (7irrigations). Total numbers of irrigations applied were reduced from 16 (under $T_{1}$ ) to 8 (under $T_{5}$ ). The use of black plastic mulch may be beneficial as it helped to conserve moisture under DI regime which is comparable to those in well irrigated vines. It may also reduce the high irrigation requirement of kiwifruit in areas where sufficient water is not available.
\end{abstract}

Keywords: Black plastic mulch, Deficit irrigation, Irrigation frequency, Kiwifruit, Soil moisture content

\section{INTRODUCTION}

The kiwifruit or Chinese gooseberry (Actinidia deliciosa Chev.) is a deciduous fruit vine, native to Yangtze valley of south and central China (Ferguson, 1984). The kiwifruit is a dioecious vine, bearing pistillate and staminate flowers separately. Kiwifruit requires 700800 chilling hours below $7^{\circ} \mathrm{C}$ and the summer temperature should not go beyond $35^{\circ} \mathrm{C}$ (Lal et al., 2010). The Kiwi fruit is unique in many ways. While most other fruits are attractive in appearance, it is dull brown in colour similar to Sapota. The flesh in cross section is however very beautiful and attractive. It is light green in colour and the seeds are soft and small. Interestingly some seeds of Chinese gooseberry i.e. Kiwi fruit were introduced in New Zealand in the beginning of 20th Century from China. New Zealand nurserymen realizing its potential as a new crop, developed cultivars and standardized its cultural practices.

In India, therefore it can be grown successfully in areas situated at elevation of $900-1800 \mathrm{~m}$ above mean sea level where, the winters are cold and summers are warm and humid, and receive well distributed annual rainfall of about $150 \mathrm{~cm}$. It can be successfully grown in Jammu and Kashmir, Himachal Pradesh, Assam, Meghalaya, Nagaland, Mizoram and hills of Tripura. A deep friable sandy loam soil, well drained and supplied with irrigation is the best for growing kiwifruit vines. In Himachal Pradesh, the area under its cultivation is 121 ha with annual production of 625 metric tons (Anonymous, 2015).

In Himachal Pradesh, however, kiwifruit cultivation has extended to those areas where, demand for water exceeds that of local resources. The problem of water limitation may prove to be a more critical constraint to temperate fruit productivity in future due to global environmental change. Secondly, the kiwifruit vines are prone to water stress mainly because of their very large leaves and very high rate of water conductivity and transpiration rate. According to Goodwin (2009) 
the water stress can be controlled under Regulated Deficit Irrigation by the application of short irrigations at specific soil moisture levels. The use of different mulching materials is known to be beneficial for in situ moisture conservation during the drought period (Guleria, 1986). Mulches also regulate soil temperature, prevent soil erosion, surface run-off of water and control the weeds. The aim of in situ moisture conservation and deficit irrigation is to maintain water stress within a desirable range so that the physiological reactions of the vine can be harnessed to the benefit of the kiwifruit grower. This type of work is of great importance in water scarce areas where the kiwifruit plants cannot fulfill their water requirement which resulted in reduction in fruit set, fruit growth and fruit size which ultimately leads to reduction in the overall production of kiwifruit.

\section{MATERIALS AND METHODS}

The present investigation was done during the years 2011 and 2012 in the Department of Fruit Science, Dr. Y. S. Parmar University of Horticulture and Forestry, Solan, HP, India. For this investigation, the uniform twenty five-year-old vines of kiwifruit cv. Allison, planted at $6 \times 4 \mathrm{~m}$ spacing on T-bar training system were selected. The seven irrigation treatments viz., irrigation at 80 per cent $\left(T_{1}\right), 60$ per cent $\left(T_{2}\right)$ and 40 per cent Field Capacity $\left(\mathrm{T}_{3}\right), 60$ per cent Field Capacity $(\mathrm{FC})$ plus grass mulch $\left(\mathrm{T}_{4}\right)$ or black polythene $\left(\mathrm{T}_{5}\right)$ and 40 per cent FC plus grass mulch $\left(\mathrm{T}_{6}\right)$ or black polythene $\left(\mathrm{T}_{7}\right)$ were applied from March to October and the mulching was applied in mid- March. These treatments were arranged in Randomized Block Design (RBD) with three replicates each of one kiwifruit vine. The statistical analysis of the data was carried out as per method described by Gomez and Gomez (1984). The significance of different treatment's effect was tested at 5 per cent level of significance as suggested by Cochran and Cox (1963).

Scheduling of irrigation: Basins (measuring $3 \times 2 \mathrm{~m}$ size) of experimental vine were prepared and properly leveled at the start of the experiment in March. The first irrigation to the vines under each treatment was applied to bring the soil to field capacity level by flooding method. The soil moisture was allowed to deplete to 80,60 and 40 per cent of field capacity in the respective treatments and then, it was again brought to field capacity by applying a measured quantity of water. The quantity of water applied to bring the soil moisture to field capacity in the vine basins during each irrigation in different treatments was determined with the aid of soil moisture characteristic curve.

Soil moisture characteristic curve: The composite soil samples from vine basins $(0-60 \mathrm{~cm})$ were taken. These samples were saturated with water for 24 hours and then subjected to $-0.3,-0.5,-1.0,-5.0,-10.0$ and 15.0 atmospheric pressure using Pressure Plate apparatus (Richard, 1949). The moisture contents of the soil retained at different atmospheric pressure were determined by gravimetric method and expressed in per cent on dry weight basis (Table 1). On the basis of these observations, soil moisture characteristics curve was prepared to determine the amount of water retained by soil at different soil moisture levels, which served as a guideline to calculate the quantity of water to be applied to bring the moisture in soil at field capacity.

Calculation of quantity of water: The quantity of water applied to each experimental vine to bring the soil moisture to field capacity from 20,40 and $60 \%$ depletion level was calculated as under:

Total quantity of water applied per vine $=\mathrm{Ax} \mathrm{d}$

Where, $A=$ Basin area to be irrigated

$\mathrm{d}=$ Depth of irrigation water $(\mathrm{cm})$

The depth of irrigation water for each application was calculated by the following formula:

Depth of irrigation water $(d)=\frac{P w \times B d \times D}{100}$

Where,

$\mathrm{PW}=$ Moisture percentage to be raised

$\mathrm{Bd}=$ Bulk density of the soil $\left(1.31 \mathrm{gm} / \mathrm{cm}^{3}\right)$

$\mathrm{D}=$ Depth of root- zone to be moistened $(60 \mathrm{~cm})$

The quantity of water applied under each treatment on the basis of the above calculation was 198.1, 396.1 and 594.2 litres at 80, 60 and 40 per cent of field capacity levels, respectively.

Soil moisture: Soil moisture data were recorded using soil moisture profiler (AquaPro sensors) with soil moisture probe Model - AquaPro-PocketPro Logger by lowering the probe at 30 and $60 \mathrm{~cm}$ depth down the access tubes installed in the basins of each experimental vine. The readings were taken at fortnightly intervals during the growing season and average values were expressed in percentage.

Frequency and number of irrigation: Frequency of the irrigation applied under different treatments was calculated by counting the number of days between two consecutive irrigations. The number of irrigations applied under these treatments over the growing period was calculated during both the year of study.

\section{RESULTS AND DISCUSSION}

Soil moisture: The soil moisture content fluctuated greatly during the growing season of kiwifruit from March to October in both the years (Figures $1 \& 2$ ), however it also varied with different irrigation treat-

Table 1. Soil moisture level at different atmospheric tensions in kiwifruit vineyard.

\begin{tabular}{cc}
\hline Tension (bars) & Moisture (\%) \\
\hline-0.3 & 21.03 \\
-0.5 & 17.80 \\
-1.0 & 13.57 \\
-5.0 & 7.87 \\
-10.0 & 6.07 \\
-15.0 & 4.82 \\
\hline
\end{tabular}


Preet Pratima et al. / J. Appl. \& Nat. Sci. 8 (4): 2093-2098 (2016)

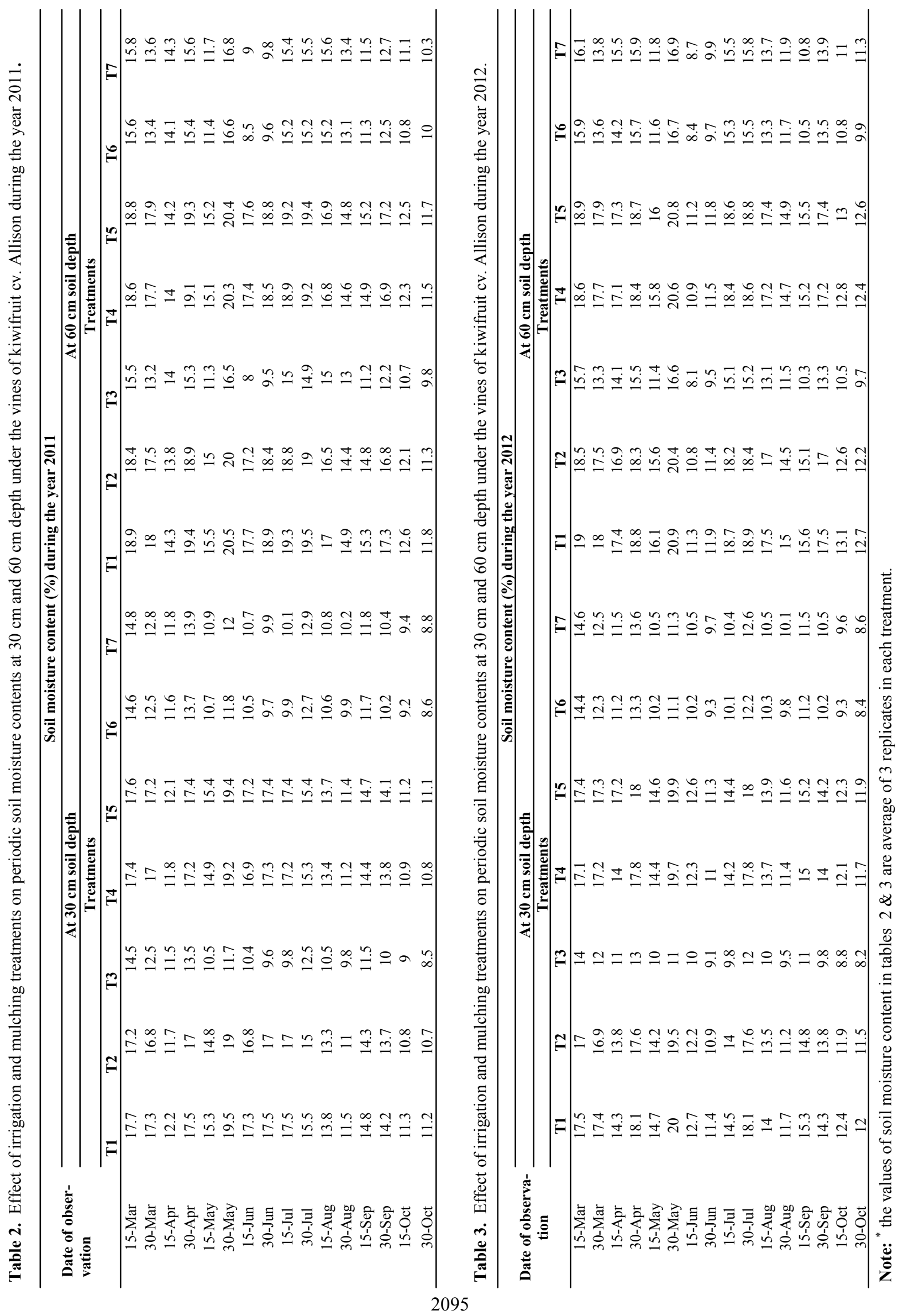


Preet Pratima et al. / J. Appl. \& Nat. Sci. 8 (4): 2093-2098 (2016)
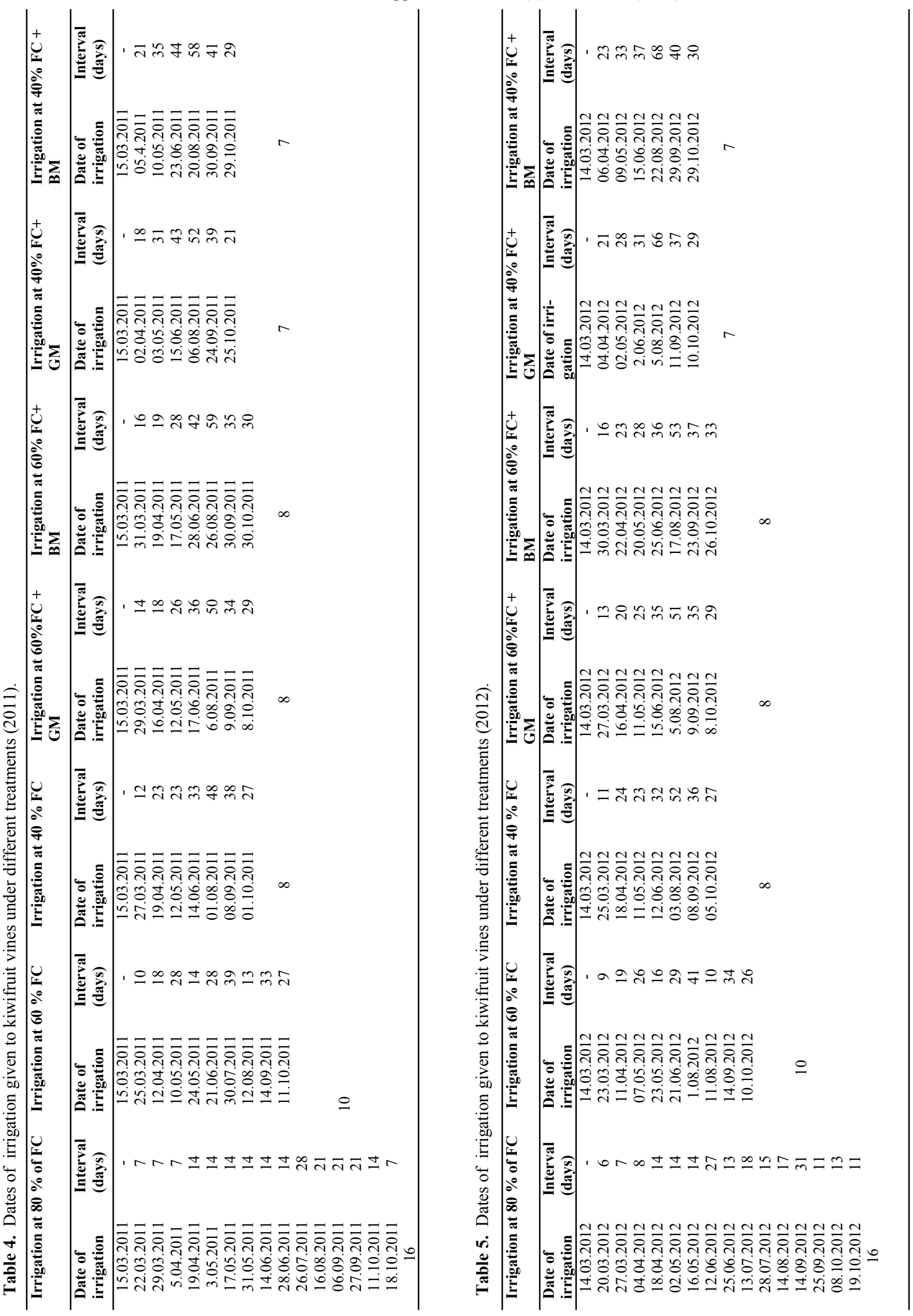


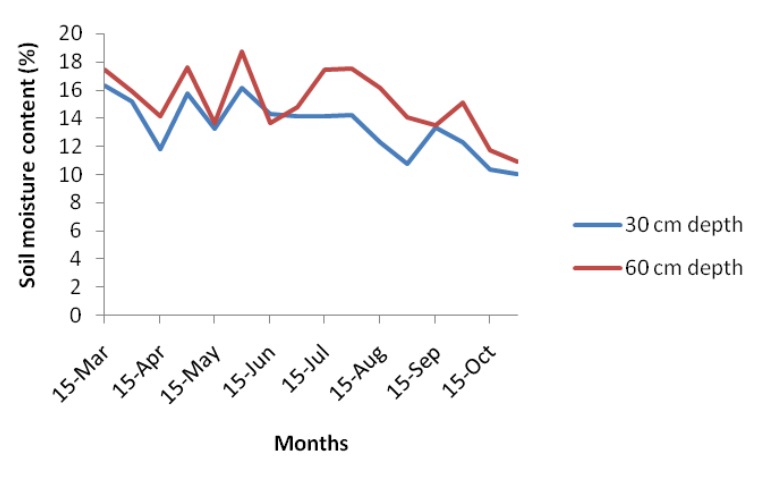

Fig. 1. Periodic variation in average soil moisture content (\%) of kiwifruit cv. Allison under different irrigation levels and in situ moisture conservation treatments at $30 \mathrm{~cm}$ and $60 \mathrm{~cm}$ soil depths during the year 2011.

ments, in situ moisture conservation techniques and with both the soil depths at 30 and $60 \mathrm{~cm}$. In the year 2011 , at $30 \mathrm{~cm}$ of soil depth greatly higher soil moisture content was recorded in the month of May under $\mathrm{T}_{1}, \mathrm{~T}_{4} \& \mathrm{~T}_{5}$ and the least soil moisture contents were observed in $\mathrm{T}_{3}$ in the month of October. However, at $60 \mathrm{~cm}$ depth the soil moisture content was highest in the month of May under $\mathrm{T}_{1}$ followed by $\mathrm{T}_{5}$ and $\mathrm{T}_{4}$ during the same period (May month) and the least was observed under $\mathrm{T}_{3}$ in June (Table 2). During the year 2012, the highest soil moisture content at $30 \mathrm{~cm}$ soil depth $(20 \%)$ was recorded in the month of May under $\mathrm{T}_{1}$, followed by $\mathrm{T}_{5}$ and $\mathrm{T}_{4}$ in the decreasing order and the least moisture level was observed in October under the vines subjected to $T_{3}$. Whereas, at $60 \mathrm{~cm}$ depth, the highest soil moisture content $(20.9 \%)$ was recorded in the month of May under $T_{1}$, followed by $T_{5}$ and $T_{4}$ and the least was observed under vines subjected to $T_{3}$, in the month of June (Table 3).

During the year 2011 at $30 \mathrm{~cm}$ soil depth the soil moisture content of kiwifruit cv. Allison was highest under the treatment $T_{1}(15.08)$, followed by $T_{5}(15.07)$ and $T_{4}$ (14.78) and at $60 \mathrm{~cm}$ soil depth the soil moisture content in kiwifruit vines was also recorded to be highest under $\mathrm{T}_{1}$ (16.66), followed by $\mathrm{T}_{5}$ (16.56) and $\mathrm{T}_{4}$ (16.33) (Table $2)^{*}$. During the year 2012 , at $30 \mathrm{~cm}$ soil depth, the increase in soil moisture content was more under black plastic mulch $(0.49 \%, 0.44)$ than under grass mulching $(0.20,0.20)$ over the respective Deficit Irrigation (DI) treatments given without mulching i.e. irrigation at 60 per cent FC and 40 per cent FC, respectively. Whereas, at 60 $\mathrm{cm}$ soil depth, the increase in soil moisture content was however, more under black plastic mulch $(0.39 \%, 0.52)$ than under grass mulching $(0.17,0.19)$ over the respective DI treatments without mulching. The least soil moisture content was, however, observed under $\mathrm{T}_{3}(10.78$ at $30 \mathrm{~cm}$ and 12.75 at $60 \mathrm{~cm}$ soil depth) (Table 3$)^{*}$.

Frequency and number of irrigations: The data pertaining to the frequency and number of irrigations under various levels of irrigation treatments revealed that the

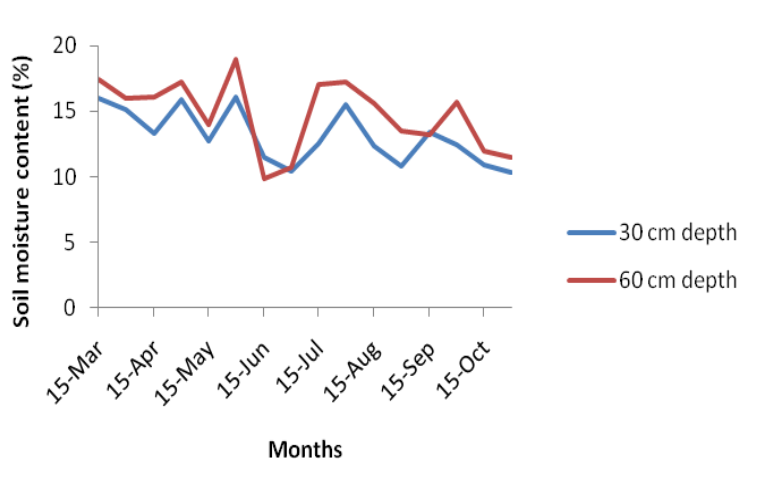

Fig. 2. Periodic variation in average soil moisture content (\%) of kiwifruit cv. Allison under different irrigation levels and in situ moisture conservation treatments at $30 \mathrm{~cm}$ and $60 \mathrm{~cm}$ soil depths during the year 2012 .

irrigation interval fluctuated not only among the treatments but also during different periods of growing season (Table $4 \& 5$ ). The maximum frequency of irrigation was recorded under irrigation applied at $80 \%$ of Field Capacity followed by irrigation at $60 \%$ of Field Capacity plus black polythene mulch treatment. The lowest frequency of irrigation was found under the irrigation treatment applied at $40 \%$ of Field Capacity. Total numbers of irrigations applied were reduced from 16 under $\mathrm{T}_{1}$ to 8 under $\mathrm{T}_{5}$. It is clear from present findings that under moderate water stress condition, the use of black plastic mulch may be beneficial as it helped to conserve moisture under DI regime which is comparable to those in well irrigated vines. It may also reduce the high irrigation requirement of kiwifruit in areas where sufficient water is not available. Earlier, it has been reported that the soil moisture decreased with Deficit Irrigation in young kiwifruit (Gucci et al., 1996); in Grape cv. Cabernet Sauvignon (Boselli et al., 1998); in Wine Grapes (Centeno et al., 2010) and increased with straw and plastic mulching in grape cv. Perlette (Phadung et al., 2005); with organic mulches plus pan evaporation replishment (PER) treatment in Mango var. Lal Sundari (Kumar et al., 2008). Total numbers of irrigations applied were reduced from 16 under standard irrigation to 8 under the treatment of Deficit Irrigation (DI) at $60 \%$ Field Capacity plus black polythene mulching, during both the years. Thus, the present findings clearly demonstrated that under moderate water stress condition, the use of black plastic mulch may be beneficial as it helped to conserve moisture under DI regime and resulted in fruit quality and production attributes comparable to those in well irrigated vines. It may also reduce the high irrigation requirement of kiwifruit in areas where sufficient water is not available.

\section{Conclusion}

In conclusion, the present study suggests that the soil moisture content decreased linearly with the water deficit condition. However, the mulch application to 
moderately water stressed kiwifruit vines markedly increase the soil moisture content. The increase in soil moisture content was however, more under black plastic mulch than under grass mulching over the respective DI treatments given without mulching. The least soil moisture content was, however, observed under irrigation treatment at $40 \% \mathrm{FC}$. The soil moisture content at $30 \mathrm{~cm}$ and $60 \mathrm{~cm}$ depths is also affected by various treatments and type of mulch material. The frequency and total number of irrigation under deficit irrigation condition alone is more, compared to those which are applied along with mulching. The total number of irrigations were reduced from 16 under standard irrigation $\left(\mathrm{T}_{1}\right)$ to 8 under deficit irrigation at 60 per cent Field Capacity along with black plastic mulch $\left(\mathrm{T}_{5}\right)$. It is clear from present findings that under moderate water stress condition, the use of black plastic mulch may be beneficial as it helped to conserve moisture under DI regime which is comparable to those in well irrigated vines. It may also reduce the high irrigation requirement of kiwifruit in areas where sufficient water is not available.

\section{REFERENCES}

Anonymous (2015). Area and production of fruits in Himachal Pradesh (2015), Department of Horticulture Himachal Pradesh, India. Horticulture Development in Himachal Pradesh at a glance : Status of Horticulture: Area under cultivation of fruit crops. www. hpagrisnet. gov. in/ hpagris/ Horticulture/ Site ID $=5$ \& Page ID $=1219$

Boselli, M., Vaio, C., Pica, B. and Di, V.C. (1998). Effect of soil moisture and transpiration on mineral content in leaves and berries of cabernet sauvignon grapevine. Journal of Plant Nutrition, 21 (6): 1163-1178

Centeno, A., Baeza, P. and Lissarrague, J.R. (2010). Relationship between soil and plant water status in wine grapes under various water deficit regimes. Horticulture Technology, 20 (3): 585-593

Cochran, G.C. and Cox, G.M. (1963). Experimental Design. Asia Publishing House, Bombay. 611p.

Ferguson, A.R. (1984). Kiwifruit: a botanical review. Horticultural Reviews, 6: 1-64

Gomez, K.A. and Gomez, A.A. (1984). Statistical procedures for agricultural research. John Willey and Son, New York. 680p.

Goodwin, Ian. (2009). Managing water stress in grape vines in Greater Victoria. Note number: AG 1074, Retrived December 2009, http:// new. dpi. vic. gov. au./ grapes/ managing water stress in grape vines, ISSN 1329-8062

Gucci, R., Massai, R., Xiloyannis, C. and James, A.F. (1996). The effect of drought and vapour pressure deficit on gas exchange of young kiwifruit (Actinidia deliciosa var. deliciosa) vines. Annals of Botany, 77: 605613

Guleria, B. (1986). Studies on the effect of different soil management systems on growth, cropping and quality of apple cv. Starking Delicious on $\mathrm{M}_{7}$ rootstock. M. Sc. Thesis, Dr. Y. S. Parmar University of Horticulture and Forestry, Nauni, Solan.

Kumar, D., Pandey, V. and Nath, V. (2008). Effect of organic mulching and irrigation schedule through drip on growth and yield of 'Lal Sundari' mango (Mangifera indica) in eastern region of India. Indian Journal of Agricultural Sciences, 78 (5): 385-388

Lal, S., Ahmed, N, Singh, S.R., Singh, D.B., MIR, J.I. and Kumar, R. (2010). Kiwifruit: Miracle Berry. Science Reporterm, 47 (07): 52-54

Phadung, T., Nilnond, S., Phavaphutanon, L. and Thongpae, S. (2005). Effects of irrigation and mulching materials on growth, yield and berry quality of 'Perlette' grape. Proceedings of $43^{\text {rd }}$ Kasetsart University Annual Conference, Thailand, pp. 459-466

Richard, L.A. (1949). Methods of measuring soil moisture tensions. Soil Science, 63: 95-112 